\title{
Metaphor Analysis in the Novel Slow Man by John Maxwell Coetzee
}

\section{Abd Al-Rahman Faraj-Allah Ibrahim Abd Al-Qader}

\begin{abstract}
This research explores metaphor as a trope of narrative in the Slow Man novel by J. M. Coetzee, 2005. The aims of this study are to identify the types and functions of metaphors in this novel. Data of the study are two speech events from the novel. The two speech events are selected on purpose as they are full of metaphors. The researcher utilises Leech's and Short's model of analysis. Tropes in general and metaphor in particular add an aesthetic and ornamented flavour to the narrative. There are other functions of metaphors, which are to stress key ideas and clarify certain concepts. The researcher has found that Coetzee in his novel Slow Man uses three types of metaphors: concretising, personifying, and synaesthetic. We read fiction not only to get new ideas, but also to enjoy ourselves by reading fiction. This is applicable in Coetzee's fiction. He plays with linguistic and literary skills available to him.
\end{abstract}

Key words: Metaphor, Leech's and Short's model, Coetzee's Slow Man.

\section{Introduction}

The present study attempts to investigate metaphor types found in J. M. Coetzee's novel Slow Man. Tropes are distinguishing characteristics of literary works. Coetzee as a linguist and a man of letters knows well how to utilise such tropes in his fiction, especially metaphors. Besides having an aesthetic function, metaphors are used to stress ideas and clarify concepts. In this study, the researcher applies Leech's and Short's model to the novel Slow Man.

\section{Aims of the Study}

The main aim of this study is to identify the types of metaphors used in the two selected speech events according to Leech's and Short's model from a cognitive linguistics perspective. Another relevant aim is to assign the used metaphors the functions they are used for.

\section{Data of the Study}

The data of the study are represented by two speech events from the novel slow man written by John Maxwell Coetzee. They are chapter one and chapter 
twenty four of the novel. The rationale behind selecting these two speech events in particular is that they are full of representative metaphors.

\subsection{Speech event number one}

Title of speech event: \#Paul Rayment's fatal accident

Chapter ONE

PAGES 1-2

THE BLOW CATCHES him from the right, sharp and surprising and painful, like a bolt of electricity, lifting him up off the bicycle. Relax! he tells himself as he flies through the air (flies through the air with the greatest of ease!), and indeed he can feel his limbs go obediently slack. Like a cat he tells himself: roll, then spring to your feet, ready for what comes next. The unusual word limber or limbre is on the horizon too.

That is not quite as it turns out, however. Whether because his legs disobey or because he is for a moment stunned (he hears rather than feels the impact of his skull on the bitumen, distant, wooden, like a mallet-blow), he does not spring to his feet at all, but on the contrary slides metre after metre, on and on, until he is quite lulled by the sliding.

He lies stretched out, at peace. It is a glorious morning. The sun's touch is kind. There are worse things than letting oneself go slack, waiting for one's strength to return. In fact there might be worse things than having a quick nap. He closes his eyes; the world tilts beneath him, rotates; he goes absent.

Once, briefly, he comes back. The body that had flown so lightly through the air has grown ponderous, so ponderous that for the life of him he cannot lift a finger. And there is someone looming over him, cutting off his air, a youngster with wiry hair and spots along his hairline. 'My bicycle,' he says to the boy, enunciating the difficult word syllable by syllable. He wants to ask what has become of his bicycle, whether it is being taken care of, since, as is well known, a bicycle can disappear in a flash; but before those words will come he is gone again.

\subsection{Speech event number two}

Title of speech event: \# The relationship between Paul and Marijana deepens

\section{Chapter TWENTY-FOUR}

PAGES 180-188 
WHEN HE INVITED Drago to stay, there was, behind the invitation, nothing that he would deem - he picks up the primly disapproving word of the day, weighs it, tests it inappropriate. His heart, as far as he can see into his heart, was and is pure, his motives innocent. He is fond of Drago with a measured, an appropriate fondness, as any man might be of an adopted son, or son-to-be.

The cohabitation he envisioned for the pair of them was to be on the mildest scale: a few companionable evenings together, Drago hunched over his homework at the dining table, he in an armchair with a book, while they waited for tempers in the casa Jokic to cool down.

But that is not how it turns out to be. Drago brings in friends; soon the flat has become as noisy and confused as a railway station. The kitchen is a mess of take-away cartons and dirty plates; the bathroom is forever occupied. None of the quiet growth in intimacy that he had looked forward to has come about. In fact, he feels that Drago is pushing him away. After the evening of the mushroom risotto they do not even eat together.

'I'm making myself an omelette for supper,' he announces as casually as he can. 'Shall I make one for you too? Ham and tomato?'

'Not for me,' says Drago. 'I'll be going out. One of my mates is picking me up. We'll get something to eat.'

'You have money?'

'Yeah, thanks, my mum gave me money.'

The mate in question is a pimply red-head named Shaun, to whom he has taken a dislike at first sight. Shaun, who according to Drago doesn't go to school much because he plays in a band, haunts the flat. He and Drago go out after dark, stay away till late, then return and shut themselves up in his ex-study, which has become Drago's room. Music and the murmur of their voices keep him awake into the early hours of the morning. Grumpy and miserable, he lies in the dark listening to the BBC.

'It is not just the noise,' he complains to Elizabeth Costello. 'Drago is used to a large family, I don't expect a monkish silence from him. No, what upsets me is the way he reacts when I dare to ask for a little consideration.'

'How does he react?' 
'A shutter falls. He does not see me any more. I might as well be a stick of furniture. Marijana says he and his father are always at loggerheads. Well, I begin to see why. I begin to sympathise with his father.'

After her cold words at the riverside, he had thought he might not see Elizabeth Costello again. But no, she is back, perhaps because she cannot give up on him, but also perhaps because she is not well. She has lost weight; she looks more than a little frail; she has a persistent cough.

'Poor Paul!' she says. 'So late in life, so monkish, as you say, so set in your ways, and now so grumpy too! What a reckless venture into childminding! In the abstract I am sure you would like to love young Drago, but the facts of life keep getting in the way. We cannot love by an act of the will, Paul. We have to learn. That is why souls descend from their realm on high and submit to being born again: so that, as they grow up in our company, they can lead us along the hard road of loving. From the beginning you have glimpsed something angelic in Drago, and I am sure you are not wrong. Drago has remained in touch with his other-worldly origins longer than most children. Overcome your disappointment, your irritation. Learn from Drago while you can. One of these days the last wisps of glory that trail behind him will vanish into the air and he will simply be one of us.

'You think I am crazy, don't you, or deluded? But remember: I have raised two children, real-life, unmystical children; you have raised none. I know what children are for; you are still ignorant. So pay heed when I speak, even when I speak in figures. We have children in order that we may learn to love and serve. Through our children we become the servants of time. Look into your heart. Ask yourself whether you have the reserves of fortitude you will need for the journey, and the stamina. If not, perhaps you should withdraw. It is not too late.'

Speaking in figures. Angels from on high. It is the most mystifying speech she has made since the hocus-pocus about the woman with the dark glasses. Is she light-headed from fasting? Is she trying to make a fool of him again? Ought he to offer her more than a cup of tea? He gives her a hard look, as hard a look as he can. But she does not waver. She believes what she is saying, it would seem. 
As for the contract solemnly concluded between Marijana and himself, that seems to have gone up in smoke. Day after day she stays away without a word of explanation. Her son, on the other hand, is blessed with frequent telephone calls. Of Drago's end of their conversations, which are in Croatian, he hears only a monosyllable here and there.

Then one afternoon, when he least expects it, Marijana drops in. Drago is not back from school; he is taking a nap.

'Mr Rayment, I wake you? Sorry - I knock and no one come. You want I make you tea?'

'No, thank you.' He is piqued at being caught asleep.

'How is your leg?'

'My leg? My leg is fine.'

A stupid question and a stupid answer. How can his leg be fine? There is no leg. The leg in question was long ago hacked off and incinerated. How is the absence of your leg?: that is what she ought to be asking. The absence of my leg is not fine, if you want the truth. The absence of my leg has left a hole in my life, as anyone with eyes in her head ought to be able to see.

Marijana has brought Ljuba with her. For the sake of the child he tries to hide his irritation.

Marijana picks her way through the mess on the floor and perches at the foot of his bed. 'You have nice life, nice and peaceful,' she says. 'Then $p f u$ ! car hit you. Then $p f u$ ! Jokic family hit you. Not so nice any more, eh? Sorry. No tea? You sure? How you and Drago get on?'

'Nothing to complain of. We get on well enough. It does me good, I am sure, to be with young people. Livens me up.'

'You and him make friend, eh? Good. Blanka say thank you.'

'It was nothing.'

'Blanka come one day to say thank you in person. But not today. She is still, you know, father's girl.' Which he takes to mean: There are still two camps among the Jokics, the father's camp and the mother's camp. And all on account of you, Paul Rayment. Because of the tempest you have unleashed. Because of the inchoate passion for your cleaning lady that you were so foolish as to declare.

'So! You have new visitor!' 
For a moment he cannot work out what she means. Then he recognises what she is holding up for inspection: the nylon stocking that Mrs Costello used to blindfold him, the stocking that for some reason he knotted around the base of the bedside lamp and forgot.

Marijana brings the stocking delicately within range of her nose. 'Lemon flower!' she says. 'Very nice! Your lady friend like lemon, eh? In Croatia, you know, we throw lemon flowers on woman and man when they get married in church. Old custom. Not rice, lemon flowers. So they have lots of children.'

Marijana's humour. Nothing subtle about it. He ought to adjust, if he aspires to one day be her mystical bridegroom and be showered with lemon petals.

'It is not what it seems,' he says. 'I am not going to explain. Just accept what I tell you. It is not what you think.'

Marijana holds the stocking at arm's length and ostentatiously lets it drop to the floor. 'You want to know what I think? I think nothing. Nothing.'

A silence falls. It is all right, he tells himself, we know each other well enough by now, Marijana and I, to have our little contretemps.

'OK,' says Marijana. 'Now I check your leg and give you wash and then we do exercise like usual. We fall behind our exercise, eh? Maybe you don't do exercise so good when you alone like. You sure you don't want prosthese?'

'I don't want a prosthesis, now or ever. The subject is closed. Please don't talk about it.'

Marijana leaves the room. Ljuba continues to stare at him with the great black-eyed stare that he finds more and more eerie. 'Hi, Ljuba,' he says. 'Ljubica.' The endearment sounds foreign in his mouth, presumptuous. The child makes no reply.

Marijana returns with the big washing-bowl. 'Private time for Mr Rayment,' she says. 'Go make picture for Mama.' She shepherds the child out, closes the door. She has taken off her sandals; her feet, he notices for the first time, are broad and flat; her toenails are painted a surprising dark red, almost purple, the colour of an angry bruise.

'You need help?' she says.

He shakes his head, slips his trousers off. 'Lie down,' she says. She spreads a discreet towel over his middle, lifts the stump onto her lap, deftly unwinds the bandage, gives the naked thing 
an approving pat. 'No prosthese, eh? You think your leg grow again, Mr Rayment? Only baby think like that - you cut it off, it grow again.'

'Marijana, please stop. We have had this conversation before. I don't want to talk - '

'OK, OK, no more talk on prosthese. You stay at home, your lady friends come visit, better that way.' She runs her thumb along the scar. 'Cheaper. No pain? No itch?'

He shakes his head.

'Good,' she says; and begins to soap the stump.

His bad humour is evaporating like the morning mist. Anything, he thinks to himself: I would give anything for... He thinks the thought with such fervour that it is impossible it does not communicate itself to Marijana. But Marijana's face is impassive. Adored, he thinks to himself. I adore this woman! Despite all! And also: She has me in the palm of her hand!

She finishes washing the stump, pats it dry, begins the first massage. After the first massage, the stretch exercises. After the stretch exercises, the second and concluding massage.

Let this go on for ever!

She must be used to it, all nurses must be used to it: men under their care growing physically excited. That must be why she is always so quick, so businesslike, why she declines to meet his eye. Presumably that is how they are taught to deal with male excitement. It will sometimes happen that... It is important to understand that... Such motions are involuntary and are an embarrassment as much to the patient as to the nurse... It is best to... Lively moments in an otherwise boring lecture.

Before the Fall, said Augustine, all motions of the body were under the direction of the soul, which partakes of God's essence. Therefore if today we find ourselves at the mercy of whimsical motions of bodily parts, that is a consequence of a fallen nature, fallen away from God. But was the blessed Augustine right? Are the motions of his own bodily parts merely whimsical? It all feels one to him, one movement: the swelling of the soul, the swelling of the heart, the swelling of desire. He cannot imagine loving God more than he loves Marijana at this moment.

Marijana is not dressed in her blue uniform, which means that she does not regard today as a working day, or at least did not regard it as such when she left home. Instead she is wearing an 
olive-green dress with a black sash and a brief slit up the left side that reveals a knee and a flash of thigh. Her bare brown arms, her smooth brown legs: Anything! he thinks again. I would give anything! And somehow this anything! and his approval of the olive-green outfit, which he finds irresistibly fetching, are no different from his love of God, who, if he does not exist, at least fills what would otherwise be a vast, all-devouring hole.

'Now on left side.' She rearranges the towel to keep him decent. 'So: press against me.'

She presses the stump backward; he is supposed to press forward countervailingly. Briefly they hold the position, the two of them: she gripping the curtailed thigh with both hands, leaning her weight against him, he gripping the edge of the bed and resisting. How far! he thinks. How near and yet how far! Breast to breast they might as well be, pushing their fallen selves into each other. If Wayne were to hear about this, what would he say! But for Wayne Blight he would never have met Marijana Jokic; but for Wayne Blight he would not have known this pressure, this love, this urgency. Felix, felix. Felix lapsus. Everything is for the best, after all.

'OK, now relax,' says Marijana. 'Good. Now on front side.'

She hitches up her dress and straddles him. On the radio, which sent him to sleep in the first place and which has not been switched off, a man is talking about the Korean car industry. Figures are up, figures are down. Marijana's hands slip under his shirt, her thumbs find a knot of pain high in the buttock and begin to caress it away. Thank you, God, he thinks. And thank God the Costello woman is not here to observe and comment.

'Što to radiš, mama?'

He opens his eyes with a start. From an arm's length away Ljuba is staring straight at him. There is no mistaking the severity of that gaze. Here he is, old and ugly and hairy and half naked and no doubt to her angelic nostrils smelly, wrestling with her mother, the two of them trapped in a posture that does not even have the repulsive majesty of intercourse.

For a moment, when the child spoke, he could feel Marijana freeze. Now she picks up the rhythm of the massage again. 'Mr Rayment has pain,' she says. 'Mama is nurse, remember?'

'That will be enough for today, Marijana,' he says, hastening to cover himself. 'Thank you.'

Marijana clambers off the bed, slips on her sandals, takes Ljuba by the hand. 'Don't suck thumb,' she says. 'Is ugly. OK, Mr Rayment. Maybe pain go away now.' 


\section{Review of the Literature}

Via a survey by the researcher, he found some works that are relevant to the topic of this study. The difference between these works and this study is that the researcher handles metaphors from a cognitive perspective, e.g. the use of a material process instead of a mental process to express a metaphor.

\subsection{Disability as Metaphor: The Nobel Prize Lectures of Faulkner, Morrison and Coetzee}

In a chapter by Pinter, Harold, entitled Disability as Metaphor: The Nobel Prize Lectures of Faulkner, Morrison and Coetzee, the author states that:

Coetzee in his critical writing explores a fascination with the workings of metaphor. His training in linguistics provides the basis for his critical analysis, which takes the constitutive nature of metaphor in language and thought as a point of departure. In an early essay, 'Isaac Newton and the Ideal of a Transparent Scientific Language' (1986) Coetzee acknowledges a critical trend in scientific writing that parallels ontag's project of stripping away metaphor: 'The overall movement in modern science has been toward a language purged of metaphoric content.' 80 Yet, Coetzee immediately counters this view by suggesting the importance of metaphor in conveying certain concepts and modes of understanding:

Some metaphors are 'constitutive of the bodies of theories that they express, rather than merely exegetical' .. .We may thus properly ask whether a metaphor-free language in which anything significant or new can be said is attainable.

This fascination with the metaphorical potential of language, and its relation to the disabling condition of speechlessness, is explored in Coetzee's Nobel Prize lecture (2003). Coetzee's interest is directed mainly at situations where the distinction between right and wrong, while crystal clear, can be seen to serve no end. Like the man in the famous Magritte painting who is studying his neck in a mirror, at the decisive moment Coetzee's characters stand behind themselves, motionless, incapable of taking part in their own actions the Swedish Academy suggests here that Coetzee's work is characterized by an endless, paralysing chain of reflections. 
Coetzee's focus on the process of representation itself, and his assertion that 'all definition is, of course, a displacement', suggests that this act of standing behind a reflection of oneself becomes incorporated into Coetzee's critical and narrative technique.

For Coetzee, the choice to mediate his lectures through this fictional framework creates a destabilizing effect, notably in the prestigious Tanner Lectures at Princeton in 1998, where he introduced his fictional persona of Costello for the first time. Yet,

this ambiguous form also suggests Coetzee's sense that displacement is necessarily at the heart of any literary narrative. This intellectual and critical 'non position [ality]' resonates with Coetzee's consistent (and much-criticized) refusal to be politically positioned as a public intellectual throughout the Apartheid regime in South Africa. Yet, the fictional characters that Coetzee creates to mediate these performances are perhaps no less artificial (or indeed dishonest) than the public persona adopted by any Nobel Prize winner for the performance of the Nobel lecture.

In the Nobel Prize lecture, the 'fiction-as-lecture' format of Elizabeth Costello is replaced with what initially appears to be a short story style narrative (as in Morrison's Nobel Prize lecture) but gradually emerges as a series of ambiguous reports of reports. Once again the process of displacement and the layering of different aesthetic frameworks are central to Coetzee's technique. Coetzee, like Morrison, begins his Nobel Prize lecture with the image of a bird. Coetzee's image is not of a conventional duck, but rather a hybrid representation of a wild bird, a semi-comic 'duckoy'. The narrator 'Robin', named after a bird himself and a shortened form of 'Robinson', explains:

The fens are home to many other kinds of birds too, writes his man, duck and mallard . . . to capture which the men of the fens, the fenmen, raise tame ducks, which they call decoy ducks or duckoys.

The linguistic play here, with the internal rhyme 'fen-men' and punning on 'decoy' creates a sense of absurdity which punctures the formality of the Nobel ceremony. Coetzee employs this opening report as, in itself, a kind of decoy. It is the first of many narrative tricks in a Nobel lecture that disrupts interpretation and shifts attention away from its own author as an object of scrutiny. The notion of a decoy, or indeed a 'duckoy', is incorporated into the narrative structure and 
characterizes Coetzee's use of metaphor throughout the lecture. The reportage structure acts as a kind of decoy, distracting attention away from the question of the actual identities of either the narrator or the report-writer.

As the lecture develops, it emerges that the dynamic is more complex:

Defoe is apparently sending reports to Crusoe. Yet, 'his man'93 doing the reporting is in fact a projection of Crusoe's imagination, as he sits drinking and scribbling in the Jolly Tar on the Bristol waterfront. This fantasy figure who 'gallops about the kingdom making his inspections'94 acts as a kind of decoy, allowing Crusoe to displace his own identity (and For Coetzee, metaphor and materiality are inextricably linked: to read disability as a metaphor is not to eclipse its physical implications entirely. Instead, a varied and shifting constellation of literal and metaphorical depictions of the disabled body become central to the way in which this author approaches the ethical, narrative and critical problem of how to conceptualize his dual roles as author and critic, as well as the process of imagining central to writing itself. Through the body, with the skin as a mediating surface and a shared point of reference for all human beings, this writer seeks out the possibility of 'a common language . . . shareable imaginative worlds'. For Coetzee, the disabled body emerges as a metaphor that, as both an author and critic, he simply 'cannot do without'.

\subsection{Coming into Being: J. M. Coetzee's Slow Mon and the Aesthetic of Hospitality}

Marais in a research entitled Coming into Being: J. M. Coetzee's Slow Mon and the Aesthetic of Hospitality, argues that very little criticism to date has examined Coetzee's use of the metaphor of hospitality in his writing. Focusing principally on Age of Iron, he briefly explores, in the first part of this essay, the incidence of this trope in this writer's earlier fiction. Thereafter, he traces his deployment of the language of hospitality in Slow Man, arguing that this metaphorical vocabulary inscribes a disjunction between the novel's medium and the kind of hospitality of which it attempts to speak. Coetzee's use of the trope of hospitality, he contends, in fact stages language's inability to achieve what this metaphor insists it must achieve. Although he does consider some of the points of intersection between his engagement with the idea of hospitality and that of thinkers such as Emmanuel Levinas and Jacques Derrida, his purpose is not to speculate on Coetzee's philosophical allegiances but to consider his understanding of the implications of the ethic of hospitality for the writing and reading of 
narrative fiction. Coetzee's concern with hospitality is evident in his extensive use in his fiction of the trope of the arrival of the stranger who precipitates change in the host who receives her.

\subsection{Age of Iron as a Cultural Text: The Question of Apartheid and the Body}

Neimneh \& Obeidat in a paper entitled 'Age of Iron as a Cultural Text: The Question of Apartheid and the Body', examine the interrelationship between the body and politics in J. M. Coetzee's 1990 novel Age of Iron from a cultural studies stand-point. Coetzee uses cancer as a trope for apartheid by way of suggesting the obscenity and fatality of such a system of segregation. Mrs. Curren, dying of cancer, metaphorically stands for the social and cultural cancer of South Africa under apartheid. Coetzee's work, our argument is, turns out to be relevant not only because of its approach to the socio-historical realities of South Africa under apartheid, but because of its cultural conception of the body within a postmodern frame. The body is metaphorically treated as a trope for the body politic. This way, Coetzee establishes a strong relationship between the body and a postmodern, popular culture whereby the body becomes a text inscribed with cultural meanings and serving socio-political ends. Against Susan Sontag's argument that illness is not a metaphor and that metaphoric thinking is not healthy for the sick in her book Illness as Metaphor, we argue that metaphoric thinking about illness, untruthful as it might be, is still an apt means of socio-political commentary since we look at cancer and other diseases through an unavoidable metaphorical lens.

\subsection{Crippling Story: Disability and Storytelling in J. M. Coetzee's Slow Man}

DOLCEROCCA in an article entitled Crippling Story: Disability and Storytelling in J. M. Coetzee's Slow Man, 2017, explores disability as a trope of storytelling in this novel. Although much has been written on the novel's narrative experiments, very little criticism to date has examined the question of disability in the novel. This article aims to remedy this gap and offers a close reading of the novel that brings together the trope of disability and meta-fictional elements in the novel. The protagonist's disability and insistent refusal of prosthesis becomes the central metaphor for narrational impairment. The novel unfolds in a sequence of covering and recovering an originary lack, beginning with the supposed author Elizabeth Costello's intervention to revitalize her tedious story, followed by a series of other transgressions. This article argues that the theme of disability allows 
for the examination of fictionality, subverting the power of the writer and exposing the inner workings and problems of fiction writing. It gives the novel a mode of structural freedom while violating the modes of fiction and bringing it to the point of collapse.

\section{Theoretical Framework}

A theoretical framework is the structure that can hold and support a theory of a research study. The researcher utilises Leech's and Short's model in this study, in particular the use of metaphor.

\subsection{Leech's and Short's Model}

According to Leech and Short (1985, p.74), every analysis of style is an attempt to find the artistic principles underlying a writer's choice of language. All writers, and for that matter, all texts, have their individual qualities. We have to make ourselves aware, for each text, of the artistic effect of the whole, and the linguistic details fit into the whole. Stylistics is thus a linguistic approach to literature, explaining the relation between language and artistic function.

The researcher will use a stylistic analysis as the actual approach. Stylistic analysis is selected because it gives an opportunity to integrate linguistic description with critical interpretation. To this end, the discourse and textual details of the work will be carefully analysed following the stylistic approach.

Thus, it is useful to have a checklist of features which may be significant in a given text, which are likely to yield stylistically relevant information. The stylistic values associated with the linguistic data must be largely taken into account. (ibid: 75).

Leach and Short (ibid: 75-82), classify items to be analysed into categories in a checklist, which are placed under four general headings: lexical categories, grammatical categories, figures of speech, and cohesion and context. Going carefully through the checklist will mean the researcher will collect some data which will turn out to be of real interpretative interest. Clearly, it would be sensible, when one writes up his analysis, only to present the findings which are 
significant, in the sense that they bear reasonably applied directly to one's account of the text. Leech's and Short's model helps to better understand 'Stylistic Features' and how writers use various stylistic devices to enhance the construction of meaning.

The objective of using this model is to investigate thematic and aesthetic values generated by linguistic forms, values which convey the author's vision, tone and attitude, which increase the affective or emotive force of the message.

\subsubsection{Metaphor}

From Leech's and Short's model the researcher focuses on metaphor as a poetic figure of speech. Here we consider the incidence of features which are stylistically foregrounded (estrangement, de-familiarization, de-automatization, marked) by virtue of departing in some way from general norms of communication by means of the language code; for example, deviations from the linguistic code. For identifying such features, the traditional figures of speech (e.g., metaphor) are often useful categories. If such metaphors occur, what kind of special interpretation is involved (e.g., metaphors can be classified as personifying, concretising, synaesthetic, etc.)?

\section{Analysis of metaphors in the novel Slow Man}

The researcher has chosen two chapters that form two speech events. They are chapter one and chapter twenty four.

\subsection{Analysis of metaphors in speech event number one}

There are eight metaphors in this speech event:

1- "The blow catches him from the right". This metaphor is realised by a material:action process, which is originally a mental:perception process. Paul is the senser, 'from the right' is the range and phenomenon is "the blow".

2- "His legs disobey". This is a personifying metaphor. Coetzee treats Paul's legs as a person who refuses to do something. It is realised by a behavioural process. 
3- "The world tilts beneath him, rotates". This metaphor is realised by a material:action process instead of a mental process. Due to the strength of the blow, Paul imagines that the world is moving in a slope angle beneath him.

4-"rotates" refers to the world beneath him due also to the strength of the blow. This metaphor is realised by a material:action process.

5- "He goes absent". It is a metaphor realised by a material:action process used instead of a behavioural process meaning 'faints'.

6-"He comes back". This metaphor means he becomes 'conscious' again. It is realized by a material:action process to replace a behavioural process.

7-"Before those words will come", is a metaphor realised by a material: action process instead of a verbal process. It implies a verbal process.

8-"He is gone again", is a mental:feeling process realised by a material: action process, meaning he becomes 'unconscious' again.

\subsection{Analysis of metaphors in speech event number two}

There are thirteen metaphors in this speech event:

1-Coetzee uses an extended metaphor. He uses three material:action processes instead of three mental processes. "-he picks up the primly disapproving word, weighs it, tests it-inappropriate".

2-"Drago is pushing him away". This metaphor is realised by a material:action process instead of a mental process. Coetzee uses the verb "push away" to imply Paul and Drago are not in good terms with each other. He uses a physical action instead of a mental one.

3- "To whom he has taken a dislike at first sight". This metaphor is realised by a material:action process instead of a mental one. It implies that Paul disliked Shaun (Drago's friend) the moment Paul saw him. The verb "has taken" implies 'felt' dislike towards Shaun. 
4- "That trail behind him will vanish into the air". Costello talks about unattainable goals of Drago. She says the "wisps of glory" trail behind Drago and will vanish when Drago grows up and be one of them. This is an extended metaphor consists of two material:action processes instead of two mental processes, implying he will forget about his past.

5- "The absence of my leg has left a hole in my life". In this metaphor, Paul describes the agony that he feels after his leg was cut off. It is a mental process of feeling realised by a material: action process.

6-"Jokic family hit you". This metaphor shows the impact the Jokic family has on Paul's life. The verb "hit" is a material: action process that is used instead of a mental process verb implying 'bother'.

7-“The tempest you have unleashed". The tempest refers to Paul's confession of love to Marijana. Coetzee uses a material:action process instead of a mental one.

8-"His bad humour is evaporating like the morning mist". This metaphor is realised by a material: action process as if Paul's humour is like liquid that evaporates. This material:action process is used instead of a mental process.

9- "She has me in the palm of her hand". This metaphor implies that Marijana takes care of Paul very well.

10- "Why she declines to meet his eye". Coetzee wants to say that Marijana is bashful about her reaction to Paul's looks.

11- "At least fills what would otherwise be a vast, all-devouring hole". Paul's approval of Marijana's new outfit is like his love for God. And he likens himself with a container that can devour Marijana's new look, i.e., love.

12- "On the radio, which sent him to sleep". This metaphor is the type of personifying. The radio is like someone who sends Paul to sleep.

13- "Maybe pain go away now". Marijana tries to make Paul feel good and averts the attention of her daughter Ljuba away from her treatment to Paul. Marijana's daughter felt that there is something strange about her mother and Paul. This 
metaphor is realised by a material:action process instead of a mental process of feeling.

\section{Conclusion}

After analysing the metaphors that occurred in the two selected speech events from the novel Slow Man, the researcher reached some conclusions as presented below. These conclusions are justified by the practical analyses.

\subsection{Conclusions of analyses of metaphors in the novel Slow Man}

\section{(METAPHORS)}

Metaphors give literary discourse aesthetic flavour that makes readers enjoy reading. Coetzee's fiction is not intended only to give people moral lessons, but we read it to enjoy ourselves and pass time in a joyful manner. Coetzee is successful in this area of interest. Reading Coetzee's novels appeals to our minds as he is a master of literature and linguist par excellence. He uses metaphors to 'ornament' and 'beautify' his writings. I mentioned in a previous paper that Coetzee uses processes to make changes in the concerned countries and even to the whole world. In addition to this aim, he makes people enjoy his writings, especially by using lexical items and expressions that have double meanings. This makes the reader exert efforts to resolve the puzzle. Which meaning is intended? Sense A or B? There is a simple rule in the study of lexicon, which is: 'a lexeme may have more than one part of speech and every part of speech may have more than one meaning'.

In Coetzee's works, he plays with language by using 'puns' that are intended to amuse readers and urge them to use their minds and dictionaries to pick the right meaning for the right context.

There are three common functions of metaphors Coetzee uses in Slow Man in particular and in his fiction in general. They are used in an 'ornamented' and 'aesthetic' language (style) that appeals to the readers' feelings and taste. Coetzee beautifies his writings by using metaphors and other stylistics features, such as simile, pun, hyperbole, etc. The three functions are: 'personifying', 'concretising', 
and 'synaesthetic'. Other functions of metaphors include stressing, explaining, and clarifying certain ideas and to affect the attitudes and behaviour of the South African readers.

In the following section, the researcher will select an exemplifying metaphor from the ones he used in the speech events. Coetzee used metaphors in the two selected speech events. From speech event number one, there is a personifying metaphor: "His legs disobey". This is a personifying metaphor. Coetzee treats Paul's legs as a person who refuses to do something. It is realised by a behavioural process. From speech event number seven: "The absence of my leg has left a hole in my life". In this metaphor, Paul describes the agony that he feels after his leg was cut off. It is a mental process of feeling realised by a material:action process.

1- Coetzee uses recurrent metaphors that are realised by material: action processes instead of mental processes. Most of the metaphors are of this type.

2- Coetzee uses frequently three functions of metaphors:

A- Concretising, e.g., "At least fills what would otherwise be a vast, all-devouring hole," i.e., himself; B- Personifying, e.g., "his legs disobey," i.e., do not move; CSynaesthetic, e.g., "She has me in the palm of her hand," i.e., takes care of him well.

3- Coetzee uses an extended metaphor. He uses three material: action processes instead of three mental processes. "-he picks up the primly disapproving word, weighs it, tests it-inappropriate".

\section{References}

ÇANKAYA, Funda. (2018). Writing the Unspeakable: Silence and the Inarticulate Other in the Fiction of J. M. Coetzee. M A Thesis. Istanbul Bilgi University, Institute of Social Sciences, Comparative Literature Master's Degree Program.

Coetzee, John Maxwell. (1969). The English fiction of Samuel Beckett: An essay in stylistic analysis. Ph.D. The University of Texas at Austin. University Microfilms, Inc., Ann Arbor, Michigan Coetzee, John Maxwell. (1992). Doubling the point: Essays and interviews. Edited by Attwell, David. Harvard University Press. 
Coetzee, John Maxwell. (2005). Slow Man. London: Vintage Random House.

DOLCEROCCA, Özen Nergis.(2017). Crippling Story: Disability and Storytelling in J. M. Coetzee s Slow Man. Mediterranean Journal of Humanities. jh.akdeniz.edu.tr. VII/2 211-221

Fowler, Roger. (Ed.). (1966). Essays on style and language. London: Routledge and Kegan Paul.

Fowler, Roger. (1971). The language of literature. London: Routledge and Kegan Paul.

Fowler, Roger. (Ed.). (1975). Style and structure in literature. Oxford: Blackwell

Fowler, Roger. (1977). Linguistics and the novel. London: Methuen.

Fowler, Roger. (1986). Linguistic criticism. Oxford University Press.

Jolly, Rosemary Jane.(1989) Territorial Metaphor in Coetzee's Waiting for the Barbarians. Ariel, 20, pp. 69-79.

Lakoff, George \& Johnson, Mark. (1980). Metaphors we live by. The University of Chicago Press, Chicago.

Leech, G. N. \& M. H. Short. (1985). Style in fiction. London: Longman

Marais, Michael.(2009) Coming into Being: J. M. Coetzee's "Slow Man" and the Aesthetic of Hospitality. Contemporary Literature, Vol. 50, No. 2, pp. 273-298 University of Wisconsin Press. Retrieved July 28, 2016, from http://www.jstor. org/stable/20616426

Neimneh, Shadi S. (2014). Coetzee's Postmodern Bodies: Disgrace between Human and Animal Bodies. Theory and Practice in Language Studies, Vol. 4, No. 8, pp. 1569-1575, August 2014 ACADEMY PUBLISHER Manufactured in inland.doi:10.4304/tpls.4.8.15691575. ISSN 1799-2591

Neimneh, Shadi S. \& Obeidat, Marwan M. (2014). Age of Iron as a Cultural Text: The Question of Apartheid and the Body. English Language and Literature Studies; Vol. 4, No. 3; 2014 ISSN 1925-4768 E-ISSN 1925-4776.Published by Canadian Center of Science and Education doi:10.5539/ells.v4n3p1 URL: http://dx.doi.org/10.5539/ells.v4n3p1

Pinter, Harold.(2005) Disability as Metaphor: The Nobel Prize Lectures of Faulkner, Morrison and Coetzee. Chapter Five. Retrieved January 8, 2020 from Hall2012_Chapter_DisabilityAsMetaphorTheNobelPr.

Simpson, Paul. (1993). Language, ideology and point of view. Routledge, London.

Zabolotskaya, O. (2014). Author's Intention in Literary Text. The Advanced Science Journal. Volume 2014.Issue 10.87-90.

Zashchitina G.V. (2014). Communication mediators: The cognitive and pragma-stylistic aspect of tropes in modern mass media discourse. RDUN Journal of Philosophy. -2014.-N.1.-P.32-39. Department of 
the English language. Faculty Moscow State Linguistic University. Ostozhenka- Moscow, Russia. Retrieved August 19, 2019, from https:// journals.rudn.ru/philosophy/article/view11734. 